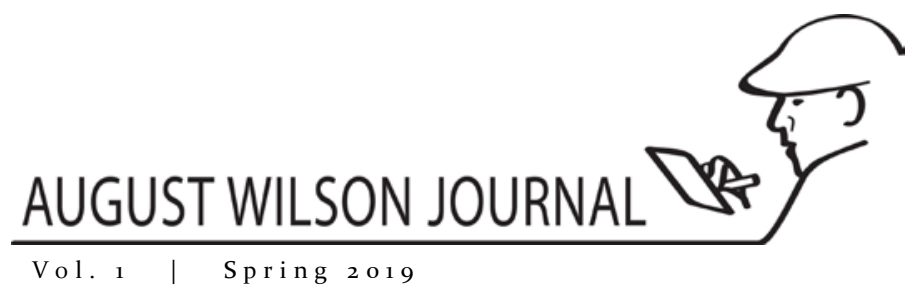

\title{
A Status Update on August Wilson House ${ }^{1}$
}

\author{
By Christopher Rawson \\ Professor Emeritus, University of Pittsburgh \\ Theater Critic, Pittsburgh Post-Gazette \\ Officer, August Wilson House
}

We expect August Wilson House to repay a debt to the Hill.

- Christopher Rawson

\begin{abstract}
August Wilson House strives to preserve the legacy of August Wilson by sponsoring and supporting such efforts as the annual Hill District Birthday Block Party, backyard productions of August's plays in collaboration with Pittsburgh Playwrights Theatre, and Visiting Fellowships in collaboration with Pittsburgh universities, such as the initial partnership with Duquesne University.

Keywords

August Wilson, Daisy Wilson, August Wilson House, Bedford Avenue, Hill District, Paul Ellis, Rob Pfaffmann, Denzel Washington, Visiting Fellowships
\end{abstract}

For years, 1727 Bedford Avenue sat as a rebuke to Pittsburgh-derelict, crumbling, windows rotting. Visiting theater artists and other pilgrims were shocked at Pittsburgh's seeming indifference to the childhood home of a great American. Born Freddy Kittel, he is known as August Wilson.

But behind the scenes, the Daisy Wilson Artist Community, Inc., named for the mother to whom he gave credit for teaching him to read when he was four and raising him with tough love, was in formation, led by August's lawyer nephew Paul Ellis and well-known preservationist architect Rob Pfaffmann. A board of directors was formed. August Wilson House (AWH) was landmarked at the local, state and national level, and it gradually raised the early funds that allowed stabilization of what would have otherwise been bulldozed into oblivion.

Starting in 2011 there were initial reconstruction projects - shoring up floors and walls, masonry patches, a temporary roof. In 2014 there was a careful reconstruction of the street façade. In 2016, there was restoration of the exterior to its appearance when August lived there, 1945-58. Severely deteriorated masonry was restored brick by brick. But the interior was still a jumble.

And then Denzel Washington came to town to film Fences, and he promised to raise the $\$ 5$ million necessary for the major reconstruction (which will involve a support

${ }^{1}$ Editor's note: Rawson explains that the intended style is to use "August Wilson House" without the "the" (capitalized or not). This aligns with other places that do not take a "the," such as Fenway Park, Hull House, Yale University. 
building and other exterior work). He made this gift public at the AWH Ground Blessing ceremony last Sept. 26: it includes \$1 million each from him, Oprah Winfrey and Tyler Perry, and substantial six-figure amounts from Samuel \& LaTanya R. Jackson, Stephanie Summers, Laurence Fishburne, Shonda Rhimes, Antoine Fuqua and John McClain (or their foundations). The capital fund was just further augmented by $\$ 1$ million from the R.K. Mellon Foundation.

Along the way there has also been steady support for pre-development, planning and stabilization both physical and operational from The Pittsburgh Foundation, Heinz Foundation, Hillman Family Foundations, African American Action Fund, McCauley Ministries plus other foundations and governmental programs, local, state and national-more than can fit in this brief status report. All this before starting a public campaign to support operations and programs so AWH won't suffer the fate of similar historic houses or small museums that open to fanfare and soon run out of funds.

While here in 1999, August visited his moldering childhood home, as the photo on this page shows. He said that if it were to be preserved, he hoped it would not be as a memorial but as "something useful." We consider that a compact between us. In addition, we've adopted a phrase of his: "Claim what is yours." We expect AWH to repay a debt to the Hill. It nurtured August and gave him the rich material for his plays, and in return the fame of its mid- $2 \mathrm{O}^{\text {th }}$ century glory days has been revived. But AWH hopes to provide the Hill with something more substantial than that.

Programming began several years ago. The first signature program was an annual Birthday Block Party, which in its fourth year has become a Hill tradition which drew 100 vendors and close to 6,00o celebrants. The second was backyard productions of August's plays in collaboration with Pittsburgh Playwrights Theatre, starting with Seven Guitars (imagined by August as taking place in that very backyard), followed by King Hedley II (which August imagined just down the block), and continuing this summer, if all the permits come through, with Gem of the Ocean staged at Aunt Ester's actual address, 1839 Wylie Avenue. The third major program is Visiting Fellowships in collaboration with Pittsburgh universities and other institutions. The inaugural fellowship, in partnership with Duquesne University, brought poet laureate Natasha Trethewey to the Hill. Future fellows in literature, art, theater or music will lean toward those younger, starting their careers.

This is a house. The spaces will be intimate, like the rooms in August's life and plays. In both, he tackled large questions of self-identity, racism and justice, but at their heart the plays dramatize conflicts between generations and within families. As a place to explore these cultural narratives, AWH will support literature and other arts on the personal scale that August first encountered them. The family's original two rooms will be as close to a memorial to Daisy and August as our compact with August will allow. By late 2020 or August's birthday in 2021, AWH will be open to both pilgrims and those drawn by workshops, roundtables, small classes, performances and, we hope, the kind of gatherings that ignited the artistic and social concerns of the young August Wilson, fired in the kiln of the Black Arts and Black Power movements of the 1960s.

We think August would find that useful.

\section{Author Bio}

A member of the board of directors of August Wilson House, Mr. Christopher Rawson is the senior theater critic at the Pittsburgh Post-Gazette where he interviewed August Wilson and reviewed Mr. Wilson's plays throughout his career. An emeritus member of the University of Pittsburgh English Department, Rawson for many years has taught a full course in August Wilson. He and Laurence A. Glasco wrote and published August Wilson: Pittsburgh Places in his Life and Plays (2015). 


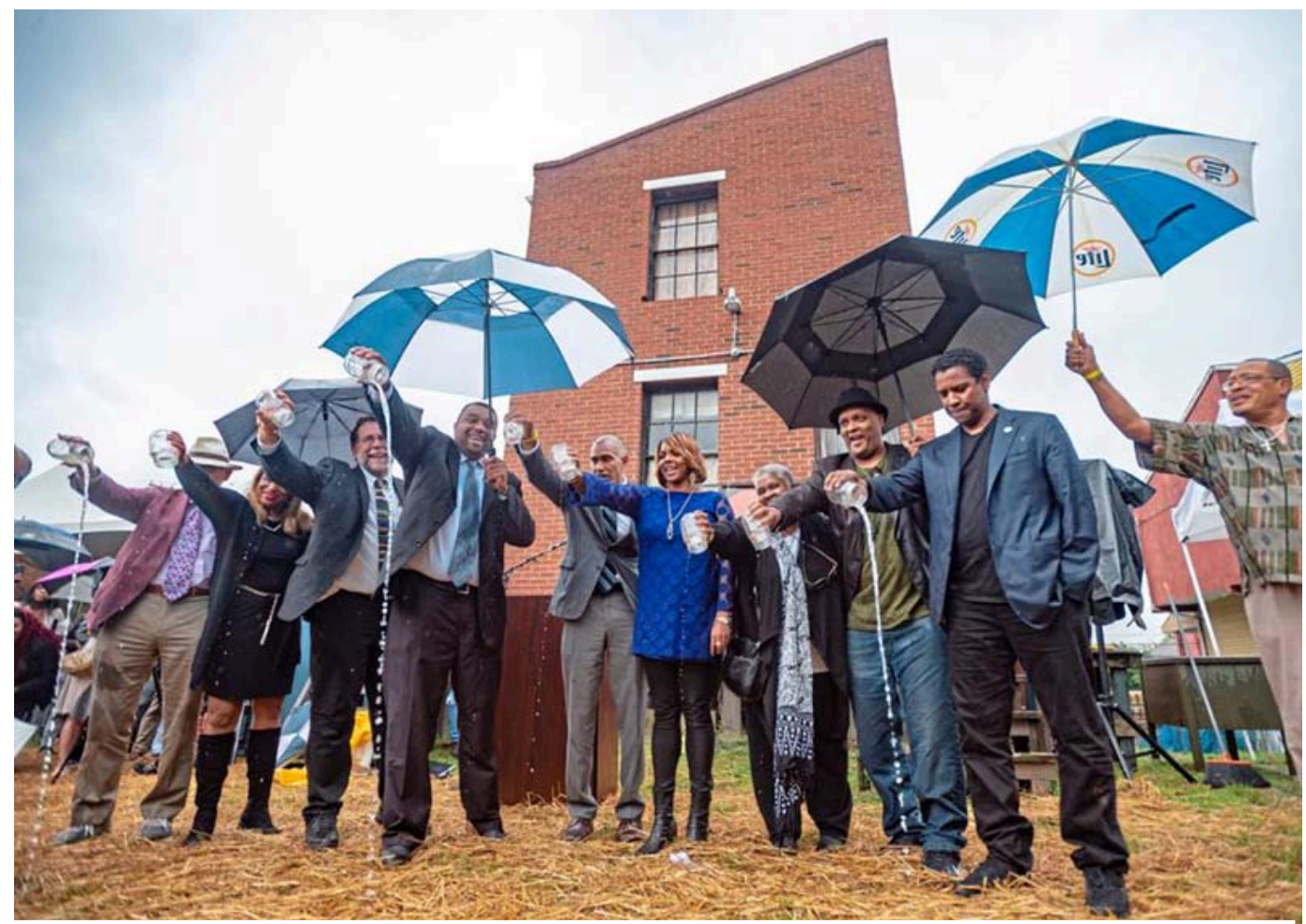

The Ground Blessing in September, 2018, when Denzel Washington announced the funds he had raised. From left: Chris Rawson, Denise Turner, Rob Pfaffmann, Paul Ellis, Richard Butler, Sakina Ansari (August's daughter), Terri Baltimore, Mark Southers, Denzel Washington, Chuck Timbers. 


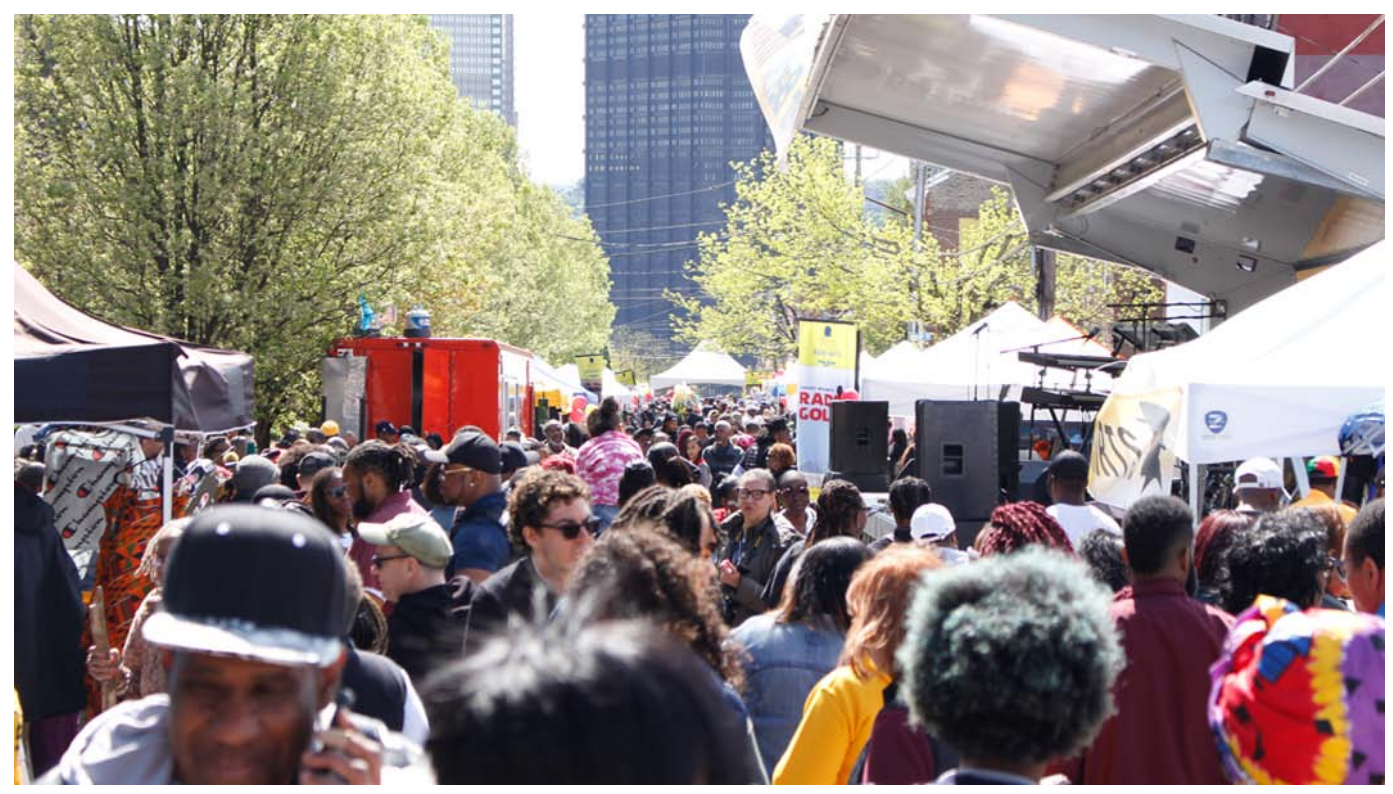

Part of the crowd of approximately 6,ooo at the April 27, 2019 AWH Birthday Block Party.

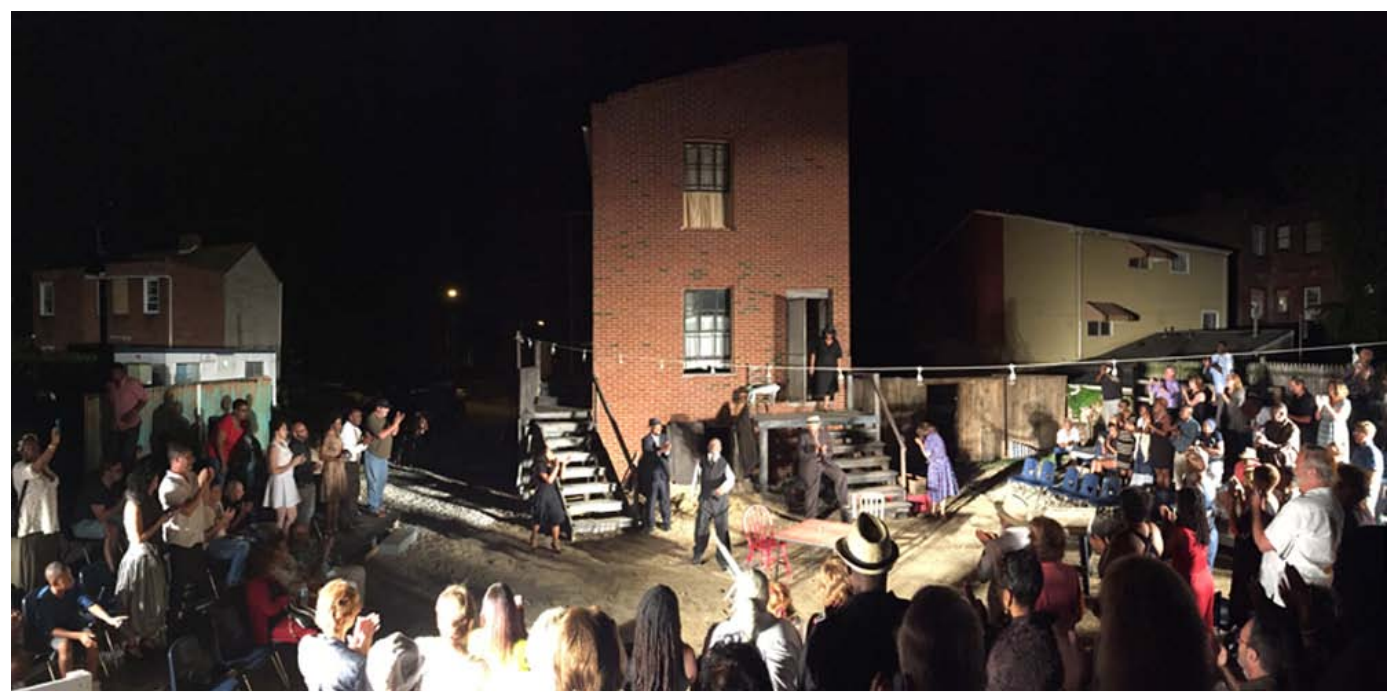

Curtain call for the 2016 production of Seven Guitars in the backyard of AWH, where the play is actually set. 